\title{
Educational Robotics: From Structured Game to Curricular Activity in Lower Secondary Schools
}

\author{
Alberto Parola, Elena Liliana Vitti, Margherita Maria Sacco, and Ilio Trafeli
}

\begin{abstract}
Many attempts have been made to introduce robotics into curricular activities, although these have largely been occasional and discontinuous experiences. These experiments are often organized to teach specific know-how, enormously devaluating the technology's potential. Furthermore, they might be placed in the hands of experts who are not on the school's staff, and who conduct the entire project mostly without the involvement of teachers. Our research project is directed at lower secondary schools. Our aim is to try to move past the dictates of "teaching robotics" towards the less controversial vision of "teaching with robotics". Following the lead of Datteri and Zecca (Metodi e tecnologie per l'uso educativo e didattico dei robot. Mondo digitale 75, editorial (2018)) we propose robots as a mediation instrument for normal learning and for transversal competencies in the school setting. The proposed research is a three-year program within the host school's normal curricular subjects and timetable, in which our approach facilitates the learning process. The topics extend beyond coding, robotics, and STEAM in general, and aim to improve experiences in liberal arts subjects such as language, literature, and geohistory.
\end{abstract}

Keywords Coding • Robotics • Competences • Predictive ability • Problem-solving $\cdot$ Imaginative ability

\section{Introduction}

Curricular programs in compulsory education in Italy are often supplemented by structured extracurricular courses delivered by freelance tutors or organizations.

In recent years, such supplementary courses are mostly designed to develop skills in STEAM subjects (science, technology, engineering, art and mathematics). This is mainly due to the emerging interest in coding and in educational robotics (National

\footnotetext{
A. Parola $(\varangle)$ · E. L. Vitti · M. M. Sacco · I. Trafeli

Centro Interdipartimentale Di Ricerca Per La Digital Education (Cinedumedia), Department of Philosophy and Educational Sciences, University of Turin, Via Verdi 8, 10124 Torino, Italy e-mail: alberto.parola@unito.it
} 
Recommendations for the School Curriculum, 2012 ${ }^{1}$; National Recommendations and New Prospects, 2018 ${ }^{2}$; National Plan for Digital Education ${ }^{3}$ ).

These private ventures are on the rise and are joined by $\mathrm{PON}^{4}$ projects which are conceived to encourage transversal skills and to strengthen normal learning. Such projects usually include robotics in structured programs with cross-disciplinary aims (Scaradozzi et al. 2015). The school environment is very dynamic and engages teachers and students alike. Many refresher courses for teachers aim to respond to the needs arising from the ongoing pedagogical and sociological revolution.

The capacity of schools to find solutions for training needs is welcome, but it is important to understand whether these integrations are indicative of an acceptable level of pedagogical consciousness and effectiveness, as underlined by Datteri and Zecca (2018): "In an area of great, positive enthusiasm for the potential of new technologies for teaching, it is particularly important to conduct theoretical and empirical research that critically analyzes the validity of this potential" (own translation). It is thus essential to find educational contexts in which to carry out empirical research over a sustained period, to investigate the significance of the courses offered to teachers and students.

In the light of these needs, the Interdepartmental Center of Research for Digital Education (Cinedumedia), of the University of Turin's Department of Philosophy and Educational Sciences took a proposal to schools and educators to take part in a long-term evaluation of their activities and verify whether the courses can be offered during curricular school time.

The research context needed the maker/provider's willingness to get involved, and the educational institution's willingness to keep the research program going for a full training cycle.

After selecting two subjects-Istituto Sociale di Torino as the host school and Kidding Srl as the provider of the B4K supplementary course on science and robotics - the main task was to understand how to transfer B4K's robotics courses, which are structured as an extra-curricular activity, to a formal school setting with curricular goals.

\footnotetext{
${ }^{1}$ Decree no. 254 of the Ministry of Education, University and Research, 16 November 2012: Indicazioni nazionali per il curricolo della scuola dell'infanzia e del primo ciclo di istruzione.

${ }^{2}$ Note no. 3645/2018 of Ministry of Education, University and Research - Indicazioni nazionali e nuovi scenari.

${ }^{3}$ Piano Nazionale Scuola Digitale (PNSD).

${ }^{4}$ National Operational Programme 2014-2020 "For School - skills and learning environments" of the Ministry of Education, University and Research.
} 


\section{Methodology of B4K Extracurricular Courses}

The Bricks4Kidz (B4K) method began in the US in 2008 and since then has spread to 43 countries. The main goal is to bring children closer to STEAM subjects using LEGO $^{\circledR}$ Technic $^{\circledR}$ and LEGO ${ }^{\circledR}$ Mindstorms ${ }^{\circledR}$.

Tutors have B4K kits and slides. The sequence and the theoretical and practical aspects are already established and must be adhered to strictly, but tutors have the freedom to choose when and how to present the topics.

The B4K goals are different from a school's general curricular targets, and before this research, it was only ever offered as an extracurricular activity in all countries where it is used.

\section{Adjustments to the Course}

The research group set about establishing which of Istituto Sociale's curricular priorities could be the subject of the B4K procedure as an educational method. The most important adjustments were:

- Including the courses during school hours;

- Increasing the number of hours in the courses;

- Establishing comparison criteria against which to measure the students' performance and improvements achieved through the B4K's courses;

- Defining didactic and cross-curricular targets, based on the host school's threeyear program of studies (PTOF);

- Encouraging a teaching style that builds knowledge actively and collectively;

- Suggesting a reorganization of the curriculum to reduce traditional classroomtaught lessons and promote the "Think-Make-Improve" approach.

To define educational targets consistent with the school's three-year study program, the research group considered the overall context of Italian schools under the existing national and European regulatory framework, beginning with the key learning competences recommended by the European Parliament (2006/962/EC). ${ }^{5}$

Specifically, the group identified the following main objectives: communication in the mother tongue; mathematical competence and basic competences in science and technology; digital competence; social and civic competences; sense of initiative and entrepreneurship.

The competence goals and the learning targets in science, technology and mathematics defined in the national recommendations for the school curriculum ${ }^{6}$ were also included to ensure all curricular activities were accounted for.

\footnotetext{
${ }^{5}$ Recommendation of the European Parliament and of the Council of 18 December 2006 on key competences for lifelong learning (2006/962/EC).

${ }^{6}$ See notes 2,3 .
} 
With these goals in mind, we proposed a robotics course in autonomous driving/self-driving to a third-year class of the lower secondary school. The topic of this course functioned on two levels: (1) it is a current topic and clearly useful for tomorrow's adults in view of the daily use of digital technology applied to mobility; (2) it allows each lesson to be structured as a problem-solving exercise applied to mobility issues that are continually changing, and for students to develop the ability to visualize space and predict the movement of an easy-to-program robot.

The traditional pattern of B4K lessons remained the same: each was divided into two parts, the first with a theoretical explanation and the second with personal experiments. However, the explanation part was designed to encourage participation, as well as active and collective knowledge construction.

\section{Performance Review}

During the fourth lesson, students took a test of the target knowledge, abilities and competences (Rychen and Salganik 2001) defined for the project. This evaluation allowed us to collect: (a) information about the students' knowledge, abilities and skills level after three lessons; (b) a summary of the results to compare against their normal performance; (c) any problematic areas that could be revised in the second part of the courses.

A code was applied to the results of these tests in order to define scores for each performance. These scores were converted into evaluations by the curricular teachers of mathematics, science and technology who were involved in the entire project. The grades assigned to special needs (SN) students were based on their individual education plans (IEP).

\section{Results}

The results show the B4K to be a viable method for reaching the knowledge targets, but the changes achieved do not sufficiently improve abilities and competences in these subjects.

Mid-course tests measure the students' competences and their ability to solve new problems, but this target was not reached. The research group assumes this failure depends on two factors: (1) students had never performed tests like this to evaluate their abilities and skills; (2) the tutor's teaching style was not designed to improve these targets.

In our opinion, in future research, the tutor's pedagogical style should be adjusted, as should the lesson structure. Less time should be devoted to theoretical explanations and more to active and collective knowledge construction. It is also important to change the duration of the course and the teachers' involvement: everyone involved should be given a role and the goal to learn the new STEAM teaching methods. 
For next year's research, it will also be important to do more work on the metacognition targets. Students must be stimulated to become more aware of their knowledge and abilities. Indeed, this year, the tutors (chosen by the B4K manager, not by the university staff) did not work actively on improving and fostering this awareness.

\section{Conclusions and New Prospects}

After this first year, the research group of Cinedumedia and Istituto Sociale decided to renew the agreement for the next three years, to experiment a new version of the courses for a full instruction cycle.

Datteri and Zecca (2018) wrote: "Educational robotics is based on the idea that, in certain conditions, robotic construction and programming can 'train' multiple aspects of reasoning and creativity related to the observation, preview, discovery and explanation of phenomena, and the identification and execution of various kinds of problem-solving strategies" (own translation). The guidelines for this research were to create these conditions.

For the next three years' research, the Cinedumedia group is fully responsible for designing the new courses and has decided to focus on these targets:

(1) Improving thinking processes (not only computational thinking, but also systemic thinking and narrative thinking);

(2) Pursuing metacognition, the key skill of "learning to learn";

(3) Consolidating preview ability and imagination skills.

Our research project is directed at lower secondary schools. Our aim is to try to move past the dictates of "teaching robotics" towards the less controversial vision of "teaching with robotics". Following the lead of Datteri and Zecca (2018) we propose robots as a mediation instrument for normal learning and for transversal competencies in the school setting. The topics extend beyond coding, robotics, and STEAM in general, and aim to improve experiences in liberal arts subjects such as language, literature, and geohistory. As Ranieri states (2011), it is important, within educational technology research, to avoid the false hope that technology alone can produce improvements. Devices do not have an intrinsic power to change learning processes, they are merely vehicles, resources for reaching a goal. The focus of educational projects should not be technology itself, but rather designing a teaching method that can achieve set targets.

\section{References}

Brick for Kidz Homepage. https://www.bricks4kidz.com/. Last accessed 06 Sept 2019

Datteri, E., Zecca, L.: Metodi e tecnologie per l'uso educativo e didattico dei robot. Mondo digitale 75, editorial (2018) 
Datteri, E., Zecca, L.: The game of science: an experiment in synthetic roboethology with primary school children. IEEE Robot. Autom. Mag. 23(2), 24-29 (2016)

Ranieri, M.: Le insidie dell'ovvio. Tecnologie educative e critica della retorica tecnocentrica, Edizioni ETS, Pisa (2011)

Rychen, D.S., Salganik, L.H.: Defining and Selecting Key Competencies. Hogrefe \& Huber Publishers, Ashland (2001)

Scaradozzi, D., Sorbi, L., Pedale, A., Valzano, M., Vergine, C.: Teaching robotics at the primary school: an innovative approach. Procedia Soc. Behav. Sci. 174, 3838-3846 (2015)

Open Access This chapter is licensed under the terms of the Creative Commons Attribution 4.0 International License (http://creativecommons.org/licenses/by/4.0/), which permits use, sharing, adaptation, distribution and reproduction in any medium or format, as long as you give appropriate credit to the original author(s) and the source, provide a link to the Creative Commons license and indicate if changes were made.

The images or other third party material in this chapter are included in the chapter's Creative Commons license, unless indicated otherwise in a credit line to the material. If material is not included in the chapter's Creative Commons license and your intended use is not permitted by statutory regulation or exceeds the permitted use, you will need to obtain permission directly from the copyright holder. 